\title{
TRANSIENT NEUROLOGICAL DEFICITS MIMICKING LEFT MIDDLE CEREBRAL ARTERY INFARCT AFTER CAROTID ARTERY STENTING WITHOUT ASSOCIATED IMAGING FINDINGS: A CASE REPORT
}

\author{
Melek KANDEMİ**, M. Savaş TEPE**, Z. Betül YALÇINER* \\ *Bayındır Hospital, Neurology Clinic, İçerenköy İSTANBUL, TURKEY \\ **Bayındır Hospital, Radiology Clinic, İçerenköy, ÍSTANBUL, TURKEY
}

\begin{abstract}
Various complications have been reported after carotid artery stenting. Ischemic lesions and hyperperfusion syndrome are well-known complications, and new cerebral microembolic lesions detected via diffusion-weighted imaging are observed in almost all patients. We describe a case who developed transient neurological deficits immediately after stenting without additional imaging findings. A 64-year-old male underwent carotid artery stenting complicated by transient neurological deficits mimicking a left middle cerebral artery infarction. The complication occurred immediately after stenting, but the symptoms resolved within less than $48 \mathrm{~h}$. Magnetic resonance imaging findings showed no signs of a new infarct, no hemorrhage, and no high signal intensity in the meninges. We conclude that the most likely pathogenesis of this complication was vasogenic edema because of vasoparalysis of the local vessels, resulting from hemodynamic changes occurring after stenting and/or biochemical effects of repeated contrast agent administration.

Keywords: Carotid artery stenting, transient neurological deficit, blood-brain barrier, reversible vasoparalysis, contrast agent.
\end{abstract}

\section{KAROTIS ARTERE STENT YERLEŞTIRME SONRASINDA İLISSSILİ GÖRÜNTÜLEME BULGUSU OLMAKSIZIN SOL ORTA SEREBRAL ARTER ENFARKTINI TAKLITT EDEN GEÇİİ NÖROLOJIK DEFISITLER: BIR OLGU SUNUMU}

ÖZET

Karotis artere stent uygulama esnasında çeşitli komplikasyonlar görülebilmektedir. İskemik lezyonlar ve hiperperfüzyon sendromu iyi bilinen komplikasyonlardır ve diffüzyon görüntüleme tekniği ile yeni serebral mikroembolik lezyonlar hemen hemen tüm hastalarda saptanmaktadır. Biz bu yazıda, stent uygulanmasından hemen sonra geçici nörolojik defisit gelişen ve ek görüntüleme bulgusu olmayan bir vaka sunmak istedik. Altmış dört yaşında erkek hastada karotis artere stent yerleştirme sonrasında sol orta serebral arter enfarktını taklit eden geçici nörolojik defisit ile karakterize bir komplikasyon gözlenmiștir. Komplikasyon stent yerleştirme işleminden hemen sonra gözlenmiş ve semptomlar 48 saat içerisinde düzelmiştir. Manyetik rezonans görüntüleme tetkiklerinde yeni enfarkt, hemoraji veya meninkslerde yüksek sinyal intensitesi gözlenmemiștir. Bu komplikasyonun en olası patogenezi olarak stent yerleștirme sonrasında meydana gelen hemodinamik değişikliklerden kaynaklanan lokal damarların vazoparalizisinin sonucu olarak gelișen vazojenik ödem ve/veya tekrarlanan kontrast madde uygulanmasının biyokimyasal etkileri olduğu düşünülmüştür.

Anahtar Sözcükler: Karotis arter stentleme, geçici nörolojik defisit, kan-beyin bariyeri, geri dönüşlü vazoparalizi, kontrast madde.

\footnotetext{
Corresponding author: Melek Kandemir, MD. Bayındır Hospital, Neurology Clinic, İçerenköy, İstanbul, Turkey.

Phone: +902165752666rail:kandemirmelek@yahoo.com

$\begin{array}{lll}\text { Received: } 06.05 .2016 & \text { Accepted: } 16.01 .2017\end{array}$

This article should be cited as following: Kandemir M, Tepe S.M, Yalçıner Z.B. Transient neurological deficits mimicking left middle cerebral artery infarct after carotid artery stenting without associated imaging findings: A case report. Turkish Journal of Cerebrovascular Diseases 2017 ; 23 (2): 75-79. doi:10.5505/tbdhd.2017.42275
} 


\section{INTRODUCTION}

Various complications have been reported after carotid artery stenting (CAS), including ischemic events, stent occlusion, hemorrhage, hyperperfusion syndrome, myocardial infarction, intestinal bleeding, contrast agent encephalopathy, delayed gadalonium enhancement of the leptomeningeal zone, and death (1-6). Further, ischemic lesions and hyperperfusion syndrome are well-known complications of CAS, and new cerebral microembolic lesions detected via diffusionweighted imaging (DWI) are observed in almost all patients after CAS $(7,8)$. Fluid-attenuated inversion recovery (FLAIR) is very sensitive in detecting leptomeningeal hyperintensity (9), which has been noted to disappear after the symptoms resolve. This phenomenon may be secondary to the vasoparalysis of local vessels caused by hemodynamic change with subsequent vasogenic edema.

We describe the case of a patient who developed transient neurological deficits immediately after CAS but without additional imaging findings. The deficits resolved within $48 \mathrm{~h}$.

\section{CASE}

A 64-year-old male with difficulty in speech was admitted to our hospital. His neurological examination revealed motor aphasia with paraphasias and slight receptive aphasia; there was no hemiparesis. The patient's risk factors for stroke included hypertension, diabetes mellitus, hyperlipidemia, atherosclerotic coronary artery disease, smoking, and alcohol. The patient underwent coronary artery bypass grafting 1 year prior to the present admission. Medications included candesartan, nebivolol, aspirin, metformin, gliclazide, and atorvastatin. An infarct in the area supplied by the superior division of the medial cerebral artery and mild cortical hyperintensity in the area supplied by the inferior division were present on DWI. No perfusion defect was seen. Magnetic resonance angiography (MRA) demonstrated occlusion of the proximal left vertebral artery, with distal filling presumably from the external circulatory system. The V4 segment of the right vertebral artery ended at the posterior inferior cerebellar artery. There was severe stenosis of the left internal carotid artery (ICA) 2 $\mathrm{cm}$ distal to its bifurcation. These findings were confirmed on computed tomograhy angiography (CTA). Arterial calcifications and atherosclerotic changes were noted in nearly all cerebral arteries. Because of long segment stenosis at the level of mandibular corner, stent angioplasty, rather than surgical endarterectomy, was decided to perform. Oral antidiabetic agents were stopped $30 \mathrm{~h}$ before digital subtraction angiography (DSA), and clopidogrel was administered before the procedure. Meanwhile, the neurological condition of the patient was stable more than $48 \mathrm{~h}$. DSA revealed $90 \%$ stenosis according to the NASCET criteria. CAS was performed under local anesthesia via a percutaneous transfemoral access by two experienced interventional radiologists. A 5-mm diameter Angioguard RX system (Cordis; Johnson \& Johnson, Warren, NJ, USA) was used for distal filter protection. Predilatation was performed using a $3 \times$ 20-mm balloon dilatation catheter (Cordis; Johnson \& Johnson). CAS was performed using the $7 \mathrm{~mm} 4$ cm PRECISE system (Cordis; Johnson \& Johnson). Heparin (5000 IU) was administered before stent delivery. After stenting, balloon angioplasty was performed once postdilatation using a balloon dilatation catheter (diameter, $5 \mathrm{~mm}$; length, $20 \mathrm{~mm}$; Cordis; Johnson \& Johnson) with a pressure of 6 atm and an occlusion time of $30 \mathrm{~s}$ (Figure I). A neurological examination during the procedure showed no new abnormalities. However, immediately after stenting, the patient became globally aphasic with only meaningless words, and he had hemiparesis on the right side. No facial asymmetry was observed. His blood pressure during the procedure varied from 120/70 to $140 / 80 \mathrm{mmHg}$. No hypo- or hyperglycemia had occurred. No cerebral vasospasm was detected on DSA during and after stenting, no new infarct area was seen on DWI, no hemorrhage was evident on gradient echo sequence, and no high signal intensity of leptomeninges was detected on FLAIR (Figure II). Contrast media that had been used included $30 \mathrm{ml}$ of gadalonium for MRA and perfusion imaging on the first day, $85 \mathrm{ml}$ of iomeprol 300 for CTA on the second day, and 150 $\mathrm{ml}$ of iomeprol 400 for DSA on the third day. Because of recurrent usage of contrast media, perfusion imaging was not performed after CAS. Doppler ultrasonography 2 and $24 \mathrm{~h}$ after stenting revealed no evidence of occlusion or thrombosis of the stent. The patient was conservatively managed 


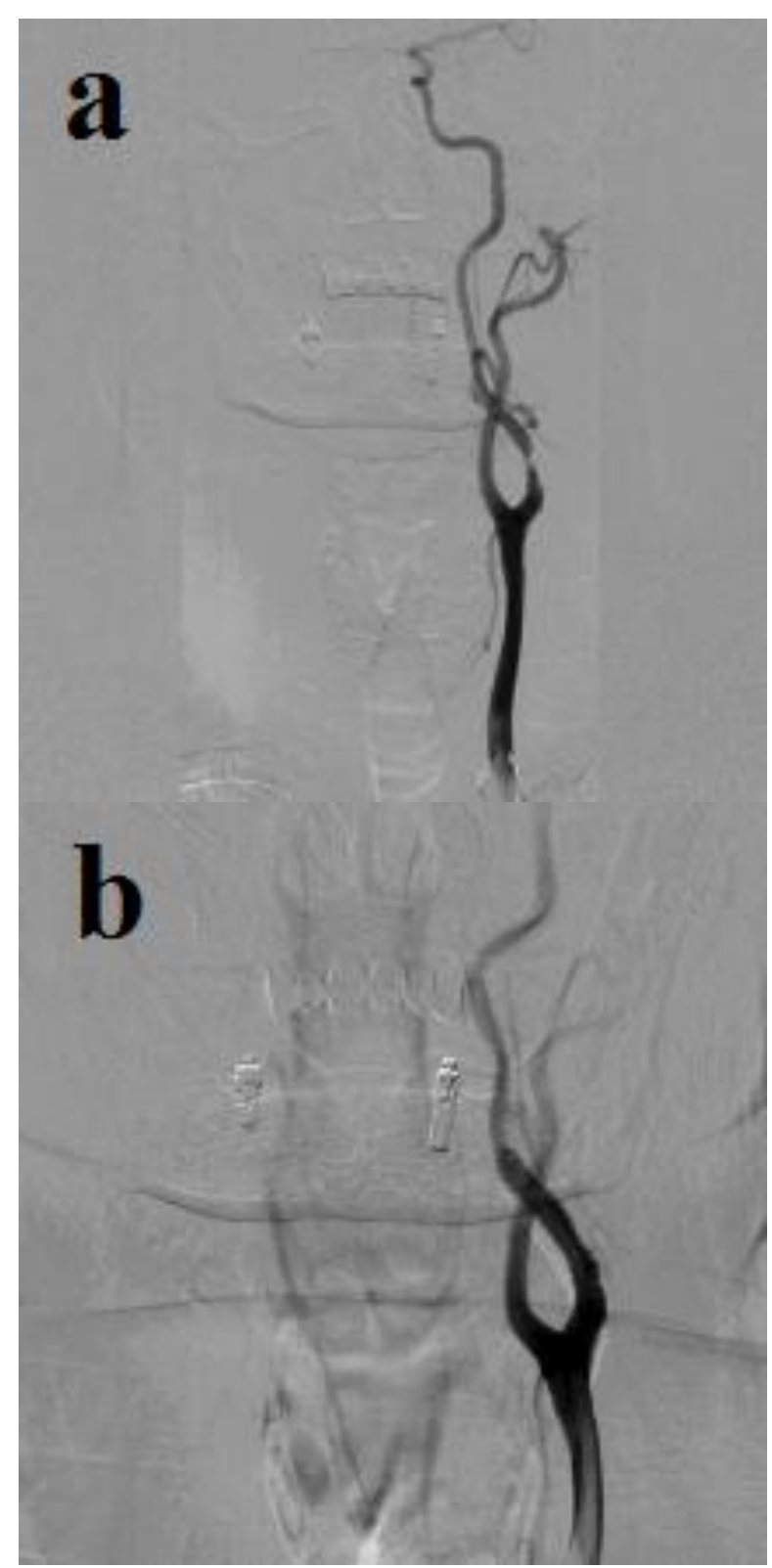

Figure I. Left carotid artery on digital subtraction angiography pre- (a) and post-stenting (b).

following CAS, including only the observation of vital signs and hydration. The severe aphasia and hemiparesis began to resolve after $24 \mathrm{~h}$, and the patient's neurological findings returned to the admission baseline within $48 \mathrm{~h}$. He was discharged from the hospital with mild motor aphasia and slight difficulty with complex commands. The patient gave informed consent and the local etthical commitee approved this report for publication.

\section{DISCUSSION}

In the current case, the complication occurred immediately after stenting and resolved in less than $48 \mathrm{~h}$. There were no new findings on magnetic resonance imaging (MRI) after the procedure, and high signal intensity of leptomeninges was not observed on the stent side on FLAIR imaging without gadolinium. No cerebral vasospasm was detected on DSA, and the ICA stent was patent on Doppler ultrasonography.

It has been shown that patients with symptomatic carotid stenosis have perfusion defects on the same side; however, cerebral perfusion defects in patients with advanced carotid atherosclerosis is not correlated with the carotid stenosis stage (10). Also, asymmetry in cerebral perfusion have continued after CAS (10). In our patient, perfusion asymmetry was not observed between both hemispheres, except for the infarct areas, before CAS. Wilkinson et al. (2000) has suggested that dilation in leptomeningeal collateral areas because of low blood flow after CAS results in susceptibility to hemodynamic changes after CAS and disrupts cerebral autoregulation (4). Because of this, neurological deficits which developed after CAS has been considered that is not depending on perfusion defect and reperfusion examination has not been made by considering the effect of contrast agents given consecutively. Although perfusion defect was not monitored, it has been considered that neurological symptoms occurred as a result of vasoparalysis, acute changes in cerebral hemodynamics and vasogenic edema after CAS due to hemodynamic instability because of advanced carotid stenosis and other coexisting cerebral vascular pathologies.

Chelates of gadolinium are commonly used as intravenous contrast agents in neuroimaging. Contrast agent encephalopathy has been identified as a complication depending on toxicity after CAS $(2,3,11)$. It presents as transient neurological deficits which is compatible with our case as a clinical course. Clinical findings have been seen immediately after CAS and recovered within a few days. Despite of the current literature, no abnormal finding such as cortical enhancement was detected in our case. However, it has been considered that the biochemical effects of contrast agents that are consecutively administered contribute to hemodynamic changes after stenting. Achieving cerebral reperfusion after thrombolytic treatment 


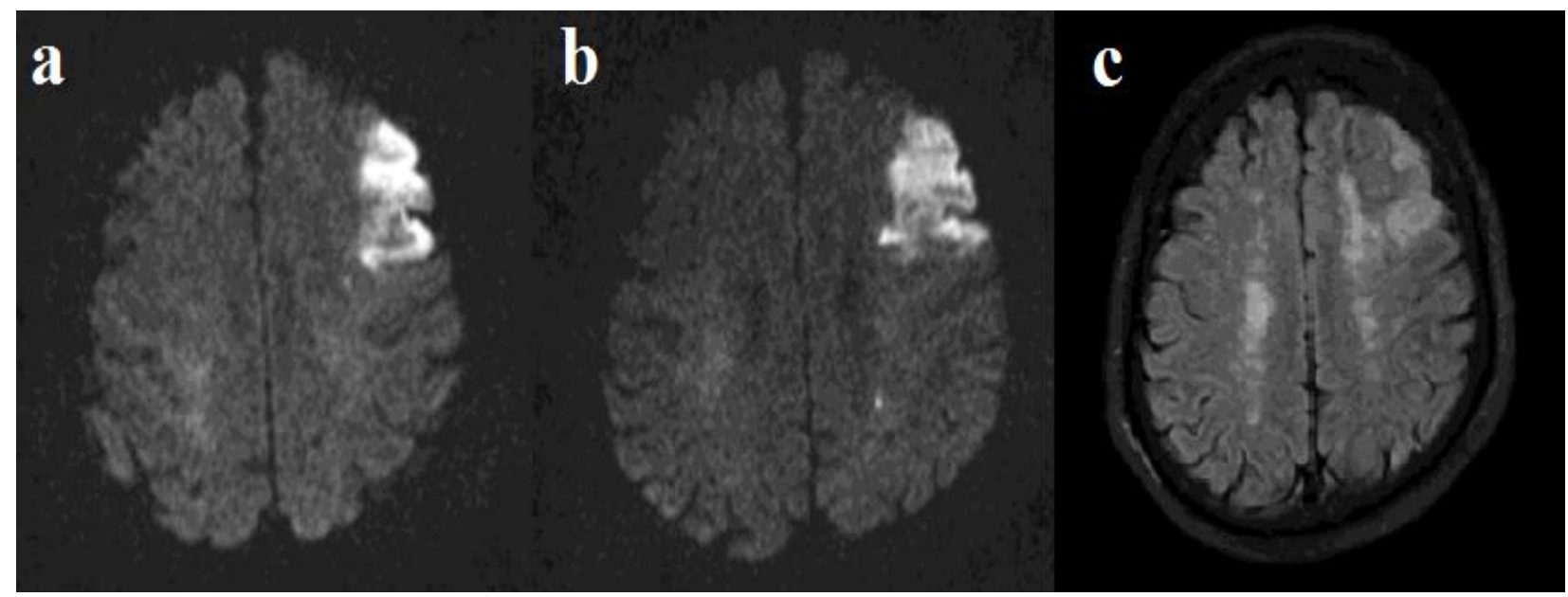

Figure II. Diffusion-weighted imaging pre- (a) and post-stenting (b); fluid-attenuated inversion recovery imaging pre-stenting (c).

and CAS, contrast agent leakage due to endothelial damage and disruption in the blood-brain barrier (BBB) have been reported $(12,13)$. This situation, seen as hyperintensity on FLAIR sequences on MRI, has been defined as an acute reperfusion marker $(12,13)$. After CAS, contrasting has been observed to increas as a result of the reversal of hemodynamics by flow recovery in the carotid system (4-6). As a rare complication of CAS, reversible neurological deficits and high signal intensities on the leptomeningeal zone on FLAIR imaging have observed $(5,6)$. It has been considered that contrast enhancement in cerebral structures appeared because of temporary impairment in BBB result of non-ionic contrast agents (14). Observing this situation in patients which stenting shows us the importance of hemodynamic changes (4). It has been suggested that recurrent administration to one vessel rather than the amount of contrast agent increases the risk (14). Another view is that BBB is damaged because of ischemic intolerance and transient occlusion with balloon in patients with advanced carotid stenosis (5). Because the MRI findings were normal $2 \mathrm{~h}$ and $24 \mathrm{~h}$ after stenting, we excluded adverse effects associated with the contrast agent. Cerebrovascular accidents in case of CAS are the most frequent complications. Asymptomatic microembolus has been reported in all cases of CAS (8). Endothelium has been damaged and the inflammatory process has been activated because of these microembolus. Also low perfusion pressure distal to the stenosis affects the clearence of microembolus (7).

Turkish Journal of Cerebrovascular Diseases 2017; 23 (2): 75-79
Maybe we can talk about decreasing of cerebral clearance of contrast agent with a similar mechanism.

Hyperperfusion syndrome has been described after CAS as well as after carotid endarterectomy (15). It is characterized by severe headache, neurological symptoms, high blood pressure, and in some cases, by hemorrhagic lesions on MRI occuring several days after the procedure (15). It is resolved by controlling the blood pressure. However, our patient's symptoms were not consistent with hyperperfusion syndrome, and his blood pressure was not elevated during hospitalization. Based on the clinical findings and lack of neuroimaging findings, neither hyperperfusion syndrome nor reversible posterior leukoencephalopathy syndrome could account for his symptoms.

Advanced carotid stenosis, especially in cases with common atherosclerosis, may cause increased exposure to toxic effects of the contrast agent by effecting brain perfusion. This effect in brain perfusion contributes to a more sensitive background for hemodynamic changes. It should be considered that this effect may take place even without showing any findings on MRI. The pathophysiology in this case might have been a disruption of BBB with hemodynamic changes and damage to the microvasculature on the side of the stent. Injury to the microvasculature may result from endothelial activation, excessive production of active oxygen species, inflammation, and edema. This may explain why the clinical symtoms were transient, resolving within two days. 


\section{REFERENCES}

1. Arslan S, Koklu E, Yuksel IO, et al. Two-year results of carotid artery stenting. Turk Kardiol Dern Ars 2014; 42: 429-434.

2. Chisci E, Setacci F, de Donato G, et al. A case of contrastinduced encephalopathy using iodixanol. J Endovasc Ther 2011; 18: 540-544.

3. Dangas G, Monsein LH, Laureno R, et al. Transient contrast encephalopathy after carotid artery stenting. J Endovasc Ther 2001; 8: 111-113.

4. Wilkinson ID, Griffiths PD, Hoggard N, et al. Unilateral leptomeningeal enhancement after carotid stent insertion detected by magnetic resonance imaging. Stroke 2000; 31: 848-851.

5. Ogami R, Nakahara T, Hamasaki O, et al. Cerebrospinal fluid enhancement on fluid attenuated inversion recovery images after carotid artery stenting with neuroprotective balloon occlusions: hemodynamic instability and bloodbrain barrier disruption. Cardiovasc Intervent Radiol 2011; 34: 936-941.

6. Fukushima Y, Nakahara I, Ohta T, Matsumoto S, et al. Rare complication characterized by late-onset transient neurological symptoms without hyperperfusion after carotid artery stenting: A report of three cases. Interv Neuroradiol 2015; 21: 72-79.

7. Orlandi G, Fanucchi S, Gallerini S, et al. Impaired clearance of microemboli and cerebrovascular symptoms during carotid stenting procedures. Arch Neurol 2005; 62: 12081211.

8. Skjelland M, Krohg-Sørensen K, Tennøe B, et al. Cerebral microemboli and brain injury during carotid artery endarterectomy and stenting. Stroke 2009; 40: 230-234.
9. Tepe S. Contrast-enhanced FLAIR versus contrastenhanced T1-weighted sequence of magnetic resonance imaging for the evaluation of leptomeningeal disease: which one is better? Arch Neuropsychiatr 2012; 49: 108113.

10. Sfyroeras GS, Arsos G, Karkos CD, et al. Interhemispheric asymmetry in brain perfusion before and after carotid stenting: a 99mTc-HMPAO SPECT study. J Endovasc Ther 2006; 13: 729-737.

11. Fang HY, Kuo YL, Wu CJ. Transient contrast encephalopathy after carotid artery stenting mimicking diffuse subarachnoid hemorrhage: a case report. Catheter Cardiovasc Interv 2009; 73: 123-126.

12. Warach S, Latour LL. Evidence of reperfusion injury, exacerbated by thrombolytic therapy, in human focal brain ischemia using a novel imaging marker of early blood-brain barrier disruption. Stroke 2004; 35 (Suppl 1): 2659-2661.

13. Köhrmann M, Struffert T, Frenzel T, et al. The hyperintense acute reperfusion marker on fluid-attenuated inversion recovery magnetic resonance imaging is caused by gadolinium in the cerebrospinal fluid. Stroke 2012; 43: 259-261.

14. Uchiyama Y, Abe T, Hirohata M, et al. Blood brain barrier disruption of nonionic iodinated contrast medium following coil embolization of a ruptured intracranial aneurysm. AJNR Am J Neuroradiol 2004; 25: 1783-1786.

15. Lieb M, Shah U, Hines GL. Cerebral hyperperfusion syndrome after carotid intervention: a review. Cardiol Rev 2012; 20: 84-89. 